\title{
INVESTMENT IN FIXED CAPITAL OF AN ENTERPRISE
}

\author{
Cherep A.V., *Kanabekova M.A., Hevorhian H.A.
}

Zaporizhzhia National University

Ukraine, 69600, Zaporizhzhia, Zhukovsky str., 66

*Abai Kazakh National Pedagogical University

Republic of Kazakhstan, 050010, Almaty, Dostyk Ave., 13

unicornuniuni1@gmail.com, cherep.av.znu@gmail.com

ORCID 0000-0001-5253-7481, 0000-0003-2392-0136, 0000-0003-1640-1995

Key words:

investment, fixed capital, capital investment, investment environment.
The investment plays an important role in an enterprise development in modern economics. The term "investment" is treated as long-term contributions of material and non-material resources with a view to further profit getting. Fixed capital of an enterprise is the part of its capital, which fully transposes its value on finished goods only in parts and over several production cycles. The investment plays an important role in macro- and micro-levels of economics.

Investments (both internal and external) are an important warehouse form for the main applications for efficient functions in Ukraine. In modern economic conditions, there is a need for constant updating, reconstruction, modernization of fixed assets to maintain a high-level enterprise competitiveness. The process of reproduction of fixed assets requires significant capital investments, which can be financed both from their own, and due to attracted sources. The article assesses the level and dynamics of investment in fixed capital, the structure of sources of investment in the reproduction of fixed asset funds has been considered, areas of increased investment activity in Ukraine have been identified.

In this article the term "investment in fixed capital" has been clarified; it has been considered the structure and role of investment for the forming of fixed capital of enterprises; it has been determined the demolition of fixed capital and has been justified the usefulness of investment in fixed capital. The investment amount has been analysed on the following indicators: type of assets, sources of financing of investment and economic activity of an enterprise. In this article functions and investment influence on fixed capital have been explored; methods of investment environment of enterprise improvement have been proposed. Methods and approaches for forming attractive investment environment of Ukrainian enterprises have been proposed.

\section{ІНВЕСТИЦІЇ В ОСНОВНИЙ КАПТТАЛ ПІДПРИЄМСТВА Череп А.В., *Канабекова М.А., Геворгян Г.А.}

Запорізький національний університет

Україна, 69600, м. Запоріжжя, вул. Жуковського, 66

*Казахський національний педагогічний університет ім. Абая

Республіка Казахстан, 050010, м. Алмати, пр. Достик, 13

\section{Ключові слова:}

інвестиції, основний капітал, капітальні інвестиції, інвестиційне середовище.
У сучасній економіці важливу роль в розвитку підприємництва відіграють інвестиції. Це поняття трактується як довгострокові внески матеріальних і нематеріальних ресурсів 3 метою подальшого отримання прибутку. Основний капітал підприємства - це частина капіталу, що повністю переносить свою вартість на готову продукцію лише по частинах та протягом кількох виробничих циклів. Інвестиції відіграють важливу роль і на макро-, і на мікрорівні економіки.

Інвестиції (внутрішні і зовнішні) є важливою складовою формування основних засобів підприємств задля ефективного функціонування підприємницької діяльності в Україні. У сучасних економічних умовах існує необхідність постійного оновлення, реконструкції, модернізації основних засобів для підтримки високого рівня конкурентоспроможності підприємства. Процес відтворення основних засобів вимагає значних капітальних вкладень, які можуть бути профінансовані за рахунок власних, а також за рахунок залучених джерел. Дається оцінка рівня, динаміки інвестицій в основний капітал, розглянуто структуру джерел інвестицій у відтворення основних коштів, визначено напрями активізації інвестиційної діяльності в Україні.

Висвітлено поняття «інвестиції в основний капітал», розглянуто структуру та роль інвестицій у формуванні основного капіталу суб'єктів 
господарювання, визначено знос основних засобів та обгрунтовано доцільність інвестування в основні засоби. Проаналізовано обсяги інвестицій за такими показниками: вид активів, джерела фінансування капіталовкладень та вид економічної діяльності підприємства. Досліджено функції та вплив інвестицій в основний капітал, запропоновано методи поліпшення інвестиційного середовища підприємств, а також методи та підходи до формування привабливого інвестиційного середовища підприємств України.

\section{Statement of the problem}

The investment plays an important role in macro- and micro-levels of economics. Considering the role of investment in the fixed capital of the enterprise, it must be noted their main functions: updating of fixed assets in the result of their moral or physical demolition, expanding the business, reducing the cost of production, etc. According to the Academic Interpretation Dictionary, the fixed capital is the part of productive capital, which is invested in means of production (premises, machines, etc.). Some enterprises of Ukraine are technologically backward precisely because of the deterioration of the fixed assets and the low rate of their renewal, the prerequisite of which is the investment passivity of the economic entities.

\section{Analysis of recent studies and publications}

The influence of investment in the fixed capital of the enterprise, the structure and sources of investment, the role of investment in the fixed capital of the enterprise were considered by both domestic and foreign scientists. Among them can be distinguished the following: V. Bazilevich [1], E. Balatsky [2], A. Goncharov [3], V. Geyetskh [4], A. Danilov [5], A. Katz [6], N. Koksharova [7], VOL. Mayorova [8], A. Melnik [9], V. Muntiyan [10], S. Pogasius [11], V. Revenko [12] and others.

In their works, the above-mentioned authors have investigated and analyzed the nature of investments, including investments in fixed capital of enterprises of various branches of the economy. It is important to point out that most authors have come to the conclusion that capital investment is important in the development of entrepreneurship. Most of these authors also considered some aspects of investment: the structure of investments, sources of their financing, the main directions of financing in enterprises of various industries.

The methods of improving the investment environment and increasing the investment attractiveness of enterprises, the role and functions of individual methods were also analyzed.

\section{Objectives of the article}

The study includes the following objectives:

- definition of the meaning of the concept of "investment in fixed capital";

- structure and statistics of fixed capital forming;
- analysis of link between investment and update of fixed capital of an enterprise;

- check-up of basic sources of funding and investment appeal of different industry enterprises of Ukraine;

- possible methods of improvement of the investment environment and involvement of capital in fixed assets.

\section{The main material of the research}

Starting a study of "investment in fixed capital", we should first clarify the meaning of "investment".

We offer to learn about the definition of "investment" by several authors. According to L.I. Pavlova, the investment is the process of using of general material, labour and financial resources, which are sent to capital increase and expansion, improvement, technical re-equipment of production, which are done in order to place a capital profitably [13]. E.J. Dolan determines investment as increase of capital amount, functioning in an economic system, that is increasing of the proposed amount of funds productions created by humans [14].

Understanding the essence of investment, we can form the essence of the following concept: "investments in fixed capital". Remembering about the essence of "fixed capital", we may conclude the following: investment in fixed capital are contributions of material, labour and financial resources which are sent to renew a fixed asset (purchase or upgrade equipment, machines, tools, etc.). In economic books, this concept is also identified with capital investments. The term "capital investment" can be defined as investment in the creation, expansion, reconstruction and technical rearmament of fixed assets, which directly influences the increase of the ability of the enterprise to achieve its strategic or operational goals. Capital investment is a part of public product, which is directed to update fixed assets [15].

According to the Table 1, it could be concluded that in the period from 2015 to 2018, depreciation of fixed assets in enterprises increased. Compared to 2017 in 2018 this indicator increased by $5.5 \%$, which indicates a low level of renewal of fixed assets and it was a negative factor in the process of business entities. It should also be noted that the initial cost of fixed assets as of 2015 (7641357 UAH) differs significantly from the same indicator in 2018 (9610000 UAH), and it increased by $1968643 \mathrm{UAH}$, which could be called positive changes in the cost of fixed assets at enterprises of Ukraine.

Table 1 - Cost of fixed assets [16].

\begin{tabular}{|l|l|l|l|}
\hline \multirow{2}{*}{ Years } & \multicolumn{2}{|c|}{ In actual prices at the end of the year, in millions UAH } & \multirow{2}{*}{ Level of demolition, in \% } \\
\cline { 2 - 4 } & Initial cost & Residual cost & \\
\hline 2015 & 7641357 & 3047839 & 60,1 \\
\hline 2016 & 8177408 & 3428908 & 58,1 \\
\hline 2017 & 7733905 & 3475242 & 55,1 \\
\hline 2018 & 9610000 & 3783494 & 60,6 \\
\hline
\end{tabular}


The lack of free financial resources is one of the obstacles to the development and upgrading of fixed assets. That is why it is necessary to create an attractive investment environment to attract capital investments by foreign and domestic investors.

The volume of capital investments development of Ukrainian enterprises in the half-year of 2019 was $233,900,000 \mathrm{UAH}$, that was by $12.3 \%$ more than capital investment for the corresponding period of 2018.

The leading spheres of economic activity in terms of capital investment development in the first half of 2019 were: industry $-40,3 \%$, construction $-10,8 \%$, agriculture, forestry and fishing - 10,1\%, information and telecommunications - 3, 7\%, wholesale and retail trade; repair of vehicles and motorcycles $-7,9 \%$, transport, warehousing, postal and courier services $-8,4 \%$, public administration and defence; compulsory social insurance $-5,4 \%$, real estate operations $-4,9 \%$.

Ukraine remains attractive for investments, at the same time it is not away from the world processes, it is also sufficiently integrated into the world economy and the violation of macroeconomic stability in external markets has its echo in Ukraine [17].

Considering the structure of capital investments, it is worth noting the ratio of investments by types of assets. As shown in Fig. 1, a large share of investment (35\%) comes from machines, equipment and inventory. Accordingly, 19 and $14 \%$ of all investments are attracted to vehicles and non-residential buildings.

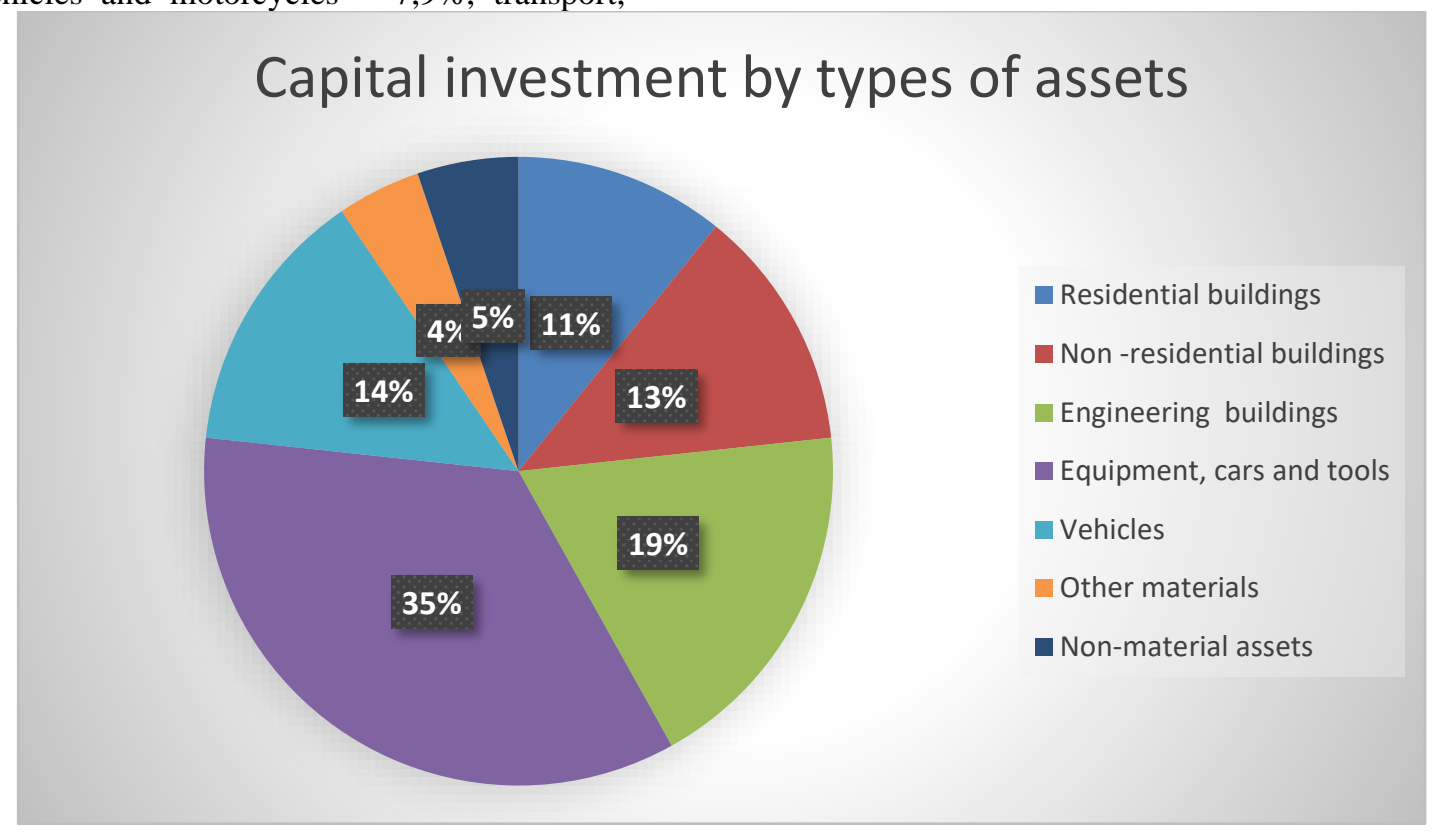

Fig.1. Capital investment by types of assets in January - March of 2019 [16].

The main source of financing of capital investments remains the own funds of enterprises and organizations. The share of bank loans and other loans in total investment has amounted to $9,1 \%$.
At the expense of state and local budgets 5,9 percent of capital investments have been mastered. Foreign investment accounted for $1,3 \%$ of total investment. Other sources of financing make up $9,6 \%$ (Fig. 2).

\section{Capital investment by sources of financing}

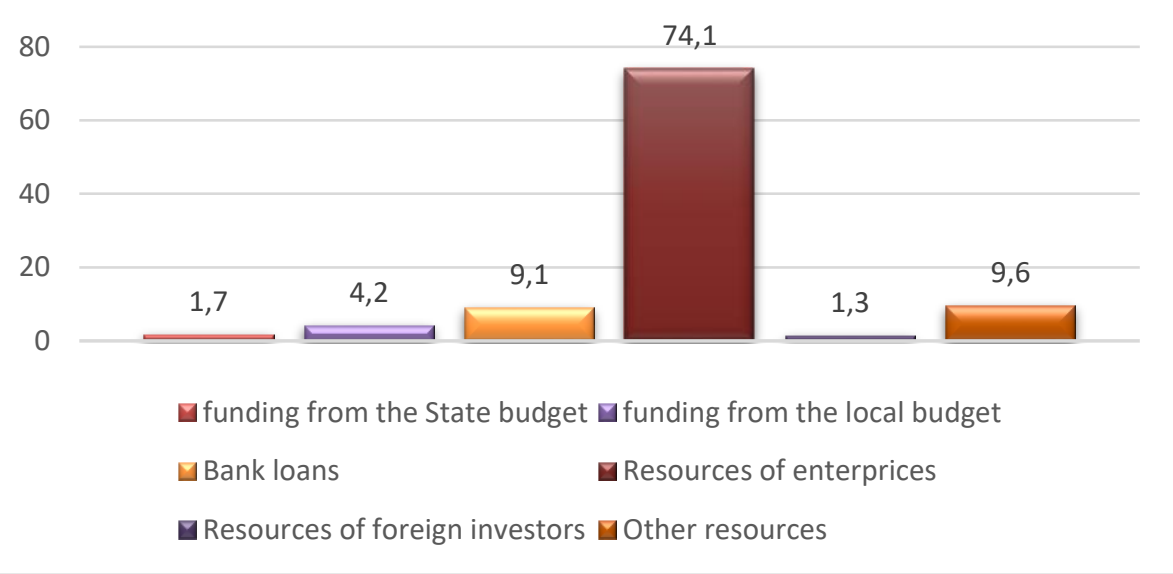

Fig. 2. Capital investment by sources of financing in January - March of 2019 [16]. 
From 2013 to 2018, we see a positive dynamic of attracting capital investments (Fig. 3). The volume of investments has increased by $322,280,100,000 \mathrm{UAH}$ in the last 6 years.

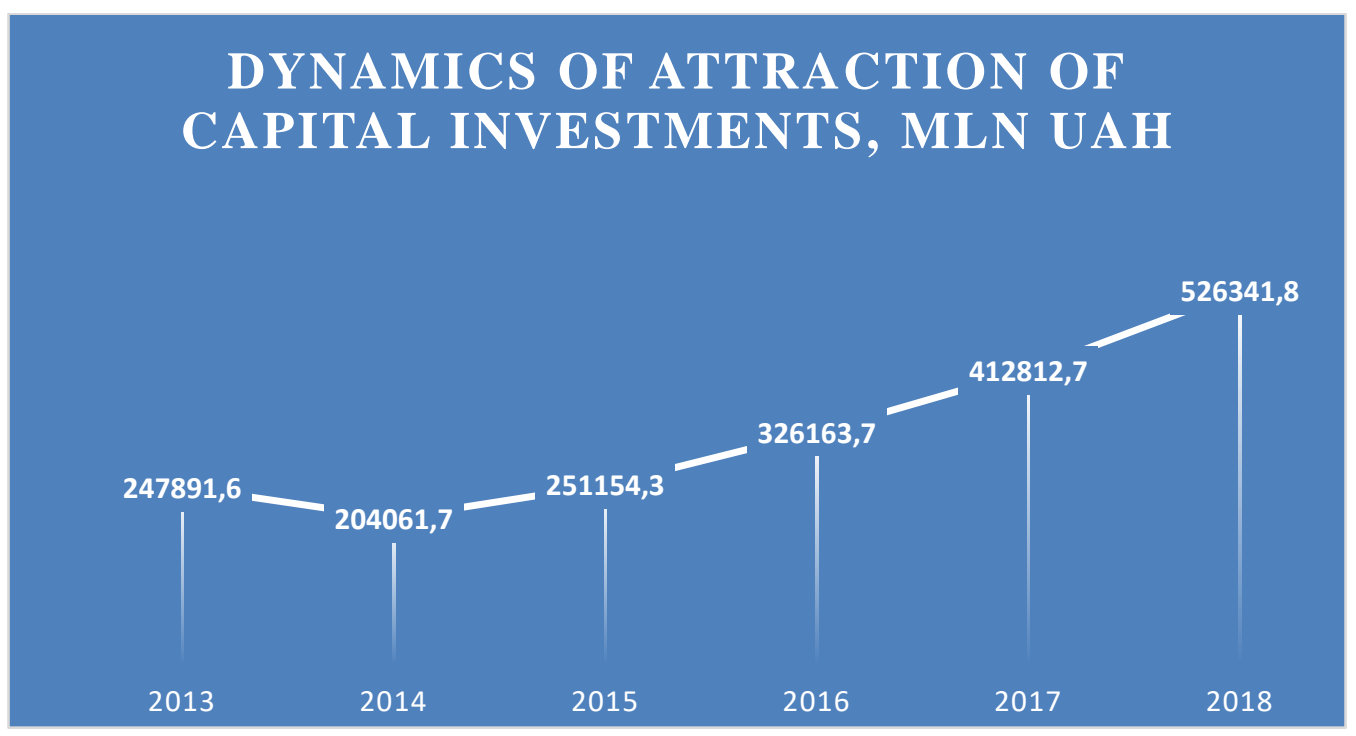

Fig. 3. Dynamics of attraction of capital investments, mln UAH [16].

The investment environment is a set of political, social and economic factors for a particular enterprise at a certain time, which are forming an interest, desire and opportunity to make investments. During the study of the literature for writing the article, the main directions and methods of improving the investment environment in Ukraine have been determined to attract more investment in the fixed capital of enterprises and not only in it. Among the methods and directions have been highlighted:

1) analysis of the activities of enterprises, especially in terms of indicators: profitability, profitability, solvency and financial stability, since enterprises with high value attract more investors;

2) evaluation of the operational and financial activities of enterprises with the aim of regulating them and improving their activities;

3) improvement of the regulatory and legal framework in the investment system;

4) improvement of the quality of the financial market and its institutions, affordable credit;

5) openness of the economy to the investment opportunities of foreign investors;
6) stabilization of the economy and minimization of possible risks.

\section{Conclusions}

Thus, investments (both domestic and foreign) are important components of formation of basic means of enterprises for effective functioning of entrepreneurial activity in Ukraine. In recent years, fixed investment has increased markedly, but it is worth continuing to improve the investment environment in order to further attract of investment. According to the statistics and conclusions drawn in this article, the most attractive investment sectors of the economy are: industry, agriculture and construction, and the main source of financing of capital investments is the own funds of enterprises.

To create an appropriate investment environment, the following main directions and methods have been proposed in the article: analysis of enterprises' activities; general stabilization of the economy; improvement of the normative and legal basis of investment. Therefore, attraction of investments in fixed capital of the enterprise is one of the important directions of the financial strategy of enterprises.

\section{References}

1. Basilevich, V.D. (2014). Ekonomichna teoriya: Politekonomiya [Economic Theory: Political Economy]. Kyiv: Znannia [ in Ukrainian].

2. Balatsky, E.O. (2015). Otsinka investytsiynoyi bezpeky rehioniv Ukrayiny [Investment security assessment of Ukrainian regions]. Mykolaivskyi natsionalnyi universytet im. V.O. Sukhomlynskoho - Nikolaev National University V.O. Sukhomlinsky, 5, 662-666 [in Ukrainian].

3. Goncharov, A.B. (2013). Formuvannya innovatsiyno-investytsiynoyi stratehiyi suchasnoho farmatsevtychnoho pidpryyemstva [Formation of innovation-investment strategy of modern pharmaceutical enterprise]. Visnyk Natsional'noho tekhnichnoho universytetu "KHPI" - Bulletin of the National Technical University "KPI", 67, 126130.) [in Ukrainian].

4. Haets, V.M. (2015). Podolannya kvazirynkovosti - shlyakh do investytsiyno oriyentovanoyi modeli ekonomichnoho zrostannya [Overcoming quasi-marketability - the path to an investment-oriented model of economic growth.]. Ekonomika Ukrayiny - Ukraine economy, 6 (643), 4-17. [in Ukrainian]. 
5. Danilov, O.D. (2009). Investuvannya [Investing]. Irpin [in Ukrainian].

6. Katz, O.A. (2011). Instrumenty rozvytku investytsiynoyi pryvablyvosti pidpryyemstva [Instruments of development of investment attractiveness of the enterprise]. Kul'tura narodov Prichernomor'ya - Culture of the peoples of the Black Sea, 196, 34 - 36. [in Ukrainian].

7. Koksharova, N.G. (2012). Ekonomicheskaya otsenka investitsiy [Economic evaluation of investments]. Syktyvkar: SLI [in Russian].

8. Mayorova, T.V. (2004). Investytsiyna diyal'nist' [Investment activity]. Kyiv: Tsentr navchalnoi literatury [in Ukrainian].

9. Melnik, O.I. (2018) Orhanizatsiyno - ekonomichni umovy aktyvizatsiyi investytsiynoyi diyal'nosti v ahrarnomu sektori ekonomiky Ukrayiny [Organizational and economic conditions of activation of investment activity in the agrarian sector of economy of Ukraine]. Ahrosvit - Agro-world, 22, 3-9 [in Ukrainian].

10. Muntian, V.I. (1999). Ekonomichna bezpeka Ukrayiny [Economic security of Ukraine]. Kyiv: Vydavnytstvo KVShch [ in Ukrainian].

11. Pogasiy, S.O. (2009) Investytsiynyy menedzhment (v prykladakh i zavdannyakh) [Investment management (in examples and tasks)]. Kharkiv: KhNAMG [in Ukrainian].

12. Revenko, V.L. (2002) Ekonomiko-matematychni zasady ta model pilhovoho opodatkuvannia innovatsiinykh proektiv v kryzovii ekonomitsi (synerhetychnyi pidkhid). [Economic and mathematical principles and model ofpreferential taxation of innovative projects in a crisis economy (synergetic approach)]. Ekonomikomatematychne modeliuvannia sotsialno-ekonomichnykh system, 2, 20-36 [in Ukrainian].

13. Pavlova, L.I. (1998). Finansy pidpryyemstv [Finance of enterprises]. Moscow: UNITI [in Russian].

14. Dolan, E. J. (1997). Mikroekonomika [Microeconomics]. SPB [in Russian].

15. Pogrischuk, G.B. (2014). Investuvannya [Investing]. Ternopil: Ekonomichna dumka [in Ukrainian].

16. Derzhavna sluzhba statystyky Ukrayiny [State Statistics Service of Ukraine]. Retrieved from http://www.ukrstat.gov.ua12 [in Ukrainian].

17. Informatsiyno-analitychni materialy shchodo investytsiynoho klimatu v Ukrayini za I pivrichchya 2019 [Information-analytical materials on the investment climate in Ukraine for the first half of 2019]. Retrieved from: http://www.me.gov.ua/Documents/Download?id=43ae484f-01b8-4a5f-b893-3c1d77ecb78e [in Ukrainian]. 